\title{
PEMANTAUAN TUMBUH KEMBANG BALITA MELALUI KELAS BALITA DENGAN PIJAT BAYI
}

\author{
Dewi Susilawati1 ${ }^{1}$ Nila Eza Fitria ${ }^{2}$, Aida Minropa ${ }^{3}$, Nurleny $^{4}$, Rahmayeni Supri ${ }^{5}$, \\ Reca Yolanda ${ }^{6}$ \\ 1,5,6 Prodi S1 Kebidanan / STIKes MERCUBAKTIJAYA Padang \\ 2 Prodi D III Kebidanan / STIKes MERCUBAKTIJAYA Padang \\ 3 Prodi D III Keperawatan / STIKes MERCUBAKTIJAYA Padang \\ ${ }^{4}$ Prodi S1 Keperawatan / STIKes MERCUBAKTIJAYA Padang
}

E-mail: nila.ezafitria@gmail.com

\begin{tabular}{ll}
\hline Article History: & Abstrak \\
\hline Received: 04 April 2021 & Latar Belakang: Kelas Ibu Balita dapat menurunkan \\
Revised: 04 April 2021 & angka kesakitan dan kematian pada balita. Hasil \\
Accepted: 21 April 2021 & wawancara dengan wakil pimpinan Klinik \\
& MERCUBAKTIJAYA bahwa klinik belum memiliki kelas \\
& ibu balita, sementara itu salah satu pelayanan yang \\
& diberikan di klinik ini adalah Kesehatan Ibu dan Anak. \\
& Tujuan kegiatan ini adalah pembentukan kelas ibu balita \\
& sebagai upaya pemantauan dan peningkatan tumbuh \\
& kembang bayi atau balita dengan cara mengajari ibu \\
& teknik pijat bayi.
\end{tabular}

Metode: Kegiatan ini dilakukan pada tanggal 16 Januari 2021 di Klinik MERCUBAKTIJAYA dengan jumlah sasaran adalah 5 orang ibu beserta anak yang berusia 0-2 tahun.

Kata Kunci: Kelas Ibu Balita, Kegiatan ini diawali dengan pengukuran tumbuh Pijat Bayi kembang anak, dilanjutkan dengan pemberian materi tentang pijat bayi kemudian diakhiri dengan mengajari ibu teknik-teknik pijat bayi.

Hasil: Berdasarkan pemeriksaan status gizi (BB/TB) dari 5 balita, 3 orang memiliki status gizi normal dan 2 orang memiliki status gizi kurus. Sebelum diberikan edukasi tentang pijat bayi didapatkan dari 5 orang ibu balita 1 orang menjawab semua pertanyaan dengan benar dan setelah diberikan edukasi tentang pijat bayi didapatkan dari 5 orang ibu balita 3 orang menjawab semua pertanyaan dengan benar.

\begin{tabular}{l} 
Abstract \\
\hline Background: Maternal Toddler Class can reduce \\
morbidity and mortality among toddlers. The results of \\
the interview with the deputy head of the \\
MERCUBAKTIJAYA Clinic show that the clinic does not yet \\
have a mother class for toddlers, while one of the services \\
provided by this clinic is Maternal and Child Health. The \\
purpose of this activity is the formation of a mother class \\
for toddlers and optimizing infant growth and \\
development by teaching mothers baby massage \\
techniques.
\end{tabular}


Keywords: Toddler's Mother Class, Baby Massage
Method: This activity was carried out on January 16, 2021 at the MERCUBAKTIJAYA Clinic with a target number of 5 mothers and children aged 0-2 years. This activity begins with the measurement of children's growth and development, continues with the provision of material on infant massage, then ends with teaching mothers about baby massage techniques.

Result: It was found that out of 5 toddlers 3 children under five had normal nutritional status and 2 children under five had this underweight nutritional status based on the nutritional status check (BW / TB) and after being given education about baby massage it was obtained from 5 mothers 3 people answered all questions with correct.

\section{Pendahuluan}

\section{Analisis Situasi}

Anak Balita merupakan salah satu populasi paling beresiko terkena berbagai macam gangguan kesehatan. Hasil Survei Demografi dan Kesehatan Indonesia (SDKI) tahun 2017 menunjukan AKB di Indonesia sebesar 24/100.000 kelahiran hidup sedangkan angka kematian balita di Indonesia sebesar 32/100.000 kelahiran hidup (Badan Pusat Statistik, 2018). Berdasarkan Profil Dinas Kesehatan Kota Padang, jumlah AKB mengalami peningkatan di tahun 2019 dimana terdapat 70 kasus di tahun 2018 menjadi 76 kasus di tahun 2019 (Dinas Kesehatan Kota Padang, 2019).

Ada banyak program kesehatan yang telah diimplementasikan Kementrian Kesehatan mulai dari pusat hingga ke daerah-daerah misalnya buku KIA, Manajemen Terpadu Balita Sakit (MTBS), Pengengendalian penyakit menular maupun tidak menular, dan sebagainya (Herliani et al., 2018). Pelaksanaan program pemerintah dalam menurunkan angka kesakitan dan angka kematian pada bayi dan balita bisa dilaksanakan dalam kegiatan kelas ibu balita. Salah satu tujuan khusus pelaksanaan kelas ibu balita yaitu meningkatkan keterampilan ibu dalam pemberian ASI dan gizi seimbang kepada balita serta memantau pertumbuhan dan perkembangan bayi balita (Departemen Kesehatan RI, 2011).

Kelas Ibu balita merupakan kelas dimana para ibu yang mempunyai anak berusia antara 0-5 tahun secara bersama berdiskusi, saling tukar pendapat, tukar pengalaman, tentang pemenuhan pelayanan kesehatan, gizi dan stimulasi pertumbuhan dan perkembangan bayi dan balita. Kelas balita tersebut dibimbing dan oleh fasilitator serta terdokumentasi hasil pemantauan tubuh kembangnya dengan menggunakan buku KIA (Departemen Kesehatan RI, 2011).

Pelaksanaan kelas ibu balita ini sangat penting manfaatnya. Salah satu tujuannya adalah meningkatkan kemampuan ibu memantau pertumbuhan dan melaksanakan stimulasi perkembangan balita. Cara untuk mencapai tujuan ini salah satunya dengan cara mengajari ibu untuk melaksanakan pijat bayi. Pijat bayi memiliki banyak manfaat, salah satunya adalah mengoptimalkan pertumbuhan dan perkembangan anak. Pijat bayi merupakan tindakan yang dapat menstimulasi perkembangan balita (Vicente et al., 2017) 
Kota Padang banyak memiliki fasilitas kesehatan seperti RS, Klinik Kesehatan dan Puskesmas. Namun, Pelaksanaan kegiatan kelas balita untuk kota Padang hanya ada di wilayah kerja Puskesmas saja. RS dan Klinik Kesehatan belum ada yang melaksanakannya. Hasil wawancara dengan wakil pimpinan Klinik MERCUBAKTIJAYA bahwa klinik MERCUBAKTIJAYA merupakan salah satu klinik pratama yang melayani pasien BPJS di Kota Padang yang belum memiliki kelas ibu balita. Sementara itu salah satu pelayanan yang diberikan diklinik ini adalah pelayanan Kesehatan Ibu dan Anak. Dari hasil data rekan medik klinik MERCUBAKTIJAYA terdapat 10 pasien bayi balita. Oleh sebab itu tim pengabdi melaksanakan kegiatan yang bertujuan dapat memantau pertumbuhan dan perkembangan balita melalui kelas balita ini.

\section{Solusi Permasalahan}

Berdasarkan identifikasi masalah pada analisis situasi yang telah dilakukan, maka slusi yang ditawarkan adalah Pembentukan kelas Ibu Balita, memberdayakan ibu dalam mengoptimalkan pemantauan dan peningkatan tumbuh kembang balita dengan cara edukasi tentang pijat bayi.

\section{Metode Pelaksanaan}

Tahap persiapan yang dilakukan padan kegiatan ini adalah dengan melakukan koordinasi dengan TIM pengabdian kepada masyarakat untuk mempersiapkan kebutuhan selama kegiatan, melakukan koordinasi dengan pimpinan Klinik MERCUBAKTIJAYA terkait sasaran dan kapan waktu pelaksanaan.

Kegiatan pelaksanaan pengabdian masyarakat ini dilakukan pada tanggal 16 Januari 2021 di Klinik MERCUBAKTIJAYA dengan jumlah sasaran adalah 5 orang ibu beserta anak yang berusia 0-2 tahun. Kegiatan ini diawali dengan pengukuran tumbuh kembang anak, pembentukan Kelas Ibu Balita dan dilajutkan dengan pemberian materi tentang pijat bayi kemudian diakhiri dengan mengajari ibu teknik-teknik pijat bayi. Setelah pemberian materi selesai, sasaran diberikan koesioner dengan jumlah pertanyaan sebayak 10 butir terkait dengan materi untuk menilai pengetahuan ibu tentang materi yang telah dibuat

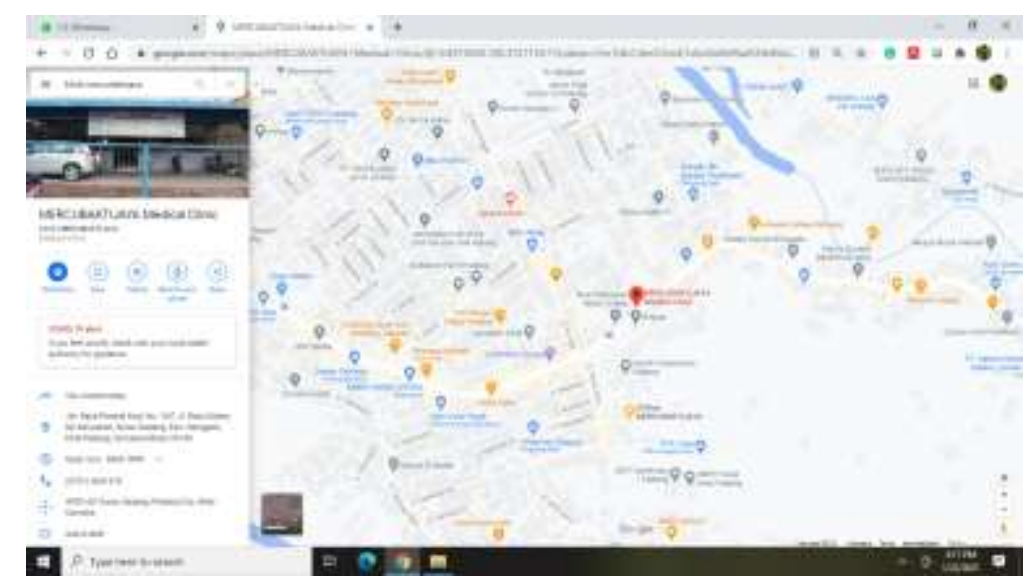

Gambar 1. Peta Lokasi Mitra (Klinik MERCUBAKTIJAYA) 
Hasil

Kegiatan pelaksaana pengabdian kepada masyarakat dilaksanakan pada tanggal 16 Januari 2021 jan 10.00-12.00 WIB di Klinik MERCUBAKTIJAYA dihadiri oleh semua TIM Pengabdi, Pegawai Klinik, dan ibu-ibu beserta anaknya sebanyak 5 orang. Hasil dari kegiatan ini adalah sebagai berikut:

Tabel 1. Hasil Pengukuran (Antropomentri) pada Balita di Klinik MERCUBAKTIJAYA

\begin{tabular}{|c|c|c|c|c|c|c|c|c|}
\hline \multirow[b]{2}{*}{ No } & \multirow[b]{2}{*}{$\begin{array}{c}\text { Nama } \\
\text { Ibu }\end{array}$} & \multirow[b]{2}{*}{$\begin{array}{c}\text { Nama } \\
\text { Anak }\end{array}$} & \multirow[b]{2}{*}{ Tanggal Lahir } & \multicolumn{5}{|c|}{ Hasil Pengukuran } \\
\hline & & & & $\begin{array}{c}\text { BB } \\
\text { (Kg) }\end{array}$ & $\begin{array}{c}\text { TB } \\
(\mathrm{cm})\end{array}$ & $\begin{array}{c}\text { Lingkar } \\
\text { Kepala } \\
\text { (cm) }\end{array}$ & $\begin{array}{l}\text { LILA } \\
\text { (cm) }\end{array}$ & $\begin{array}{c}\text { Status } \\
\text { gizi } \\
(\mathrm{BB} / \mathrm{TB})\end{array}$ \\
\hline 1 & Ny. HR & An. QN & 6 April 2020 & 8,9 & 74 & 44 & 17 & Normal \\
\hline 2 & Ny. RJ & An. AM & 28 Mei 2020 & 6,4 & 66 & 42 & 13 & Kurus \\
\hline 3 & Ny. WA & An. AP & 5 Oktober 2020 & 6,02 & 63 & 40 & 17 & Normal \\
\hline 4 & Ny. B & An. A & 6 Oktober 2020 & 6,47 & 61 & 38 & 17 & Normal \\
\hline 5 & Ny. WL & An. SQ & 15 februari 2019 & 9,4 & 85 & 49 & 16 & Kurus \\
\hline
\end{tabular}

Berdasarkan tabel 1 didapatkan bahwa dari 5 balita 3 orang balita memiliki status gizi normal dan 2 orang balita memiliki status gisi kurus ini berdasarkan pemeriksaan satustus gizi berat badan per tinggi badan (BB/TB).

Tabel 2. Distribusi Frekuensi Pengetahuan Ibu Sebelum diberikan Edukasi Pijat Bayi di Klinik MERCUBAKTIJAYA

\begin{tabular}{ccc}
\hline No & Nama Responden & Jumlah Soal yang Benar \\
\hline 1 & Ny. HR & 10 \\
\hline 2 & Ny. RJ & 8 \\
\hline 3 & Ny. WA & 7 \\
\hline 4 & Ny. B & 7 \\
\hline 5 & Ny. WL & 8 \\
\hline
\end{tabular}

Berdasarkan tabel 2 didapatkan bahwa pengetahuan ibu sebelum dilakukan edukasi masih kurang. Ini terlihat dari hasil koesioner yang diberikan dimana didapatkan dari 5 orang ibu 1 orang menjawab semua pertanyaan dengan benar.

Tabel 3. Distribusi Frekuensi Pengetahuan Ibu Setelah diberikan Edukasi Pijat Bayi Di Klinik MERCUBAKTIJAYA

\begin{tabular}{ccc}
\hline No & Nama Responden & Jumlah Soal yang Benar \\
\hline 1 & Ny. HR & 10 \\
\hline 2 & Ny. RJ & 8 \\
\hline 3 & Ny. WA & 10 \\
\hline 4 & Ny. B & 10 \\
\hline 5 & Ny. WL & 8
\end{tabular}

Berdasarkan tabel 3 didapatkan bahwa pengetahuan ibu setelah dilakukan edukasi meningkat. Ini terlihat dari hasil koesioner yang diberikan dimana didapatkan 


\section{Jurnal ABDI MERCUSUAR}

Vol. 01, No. 01, Mei, 2021, pp. 026 - 031

dari 5 orang ibu 3 orang menjawab semua pertanyaan dengan benar.
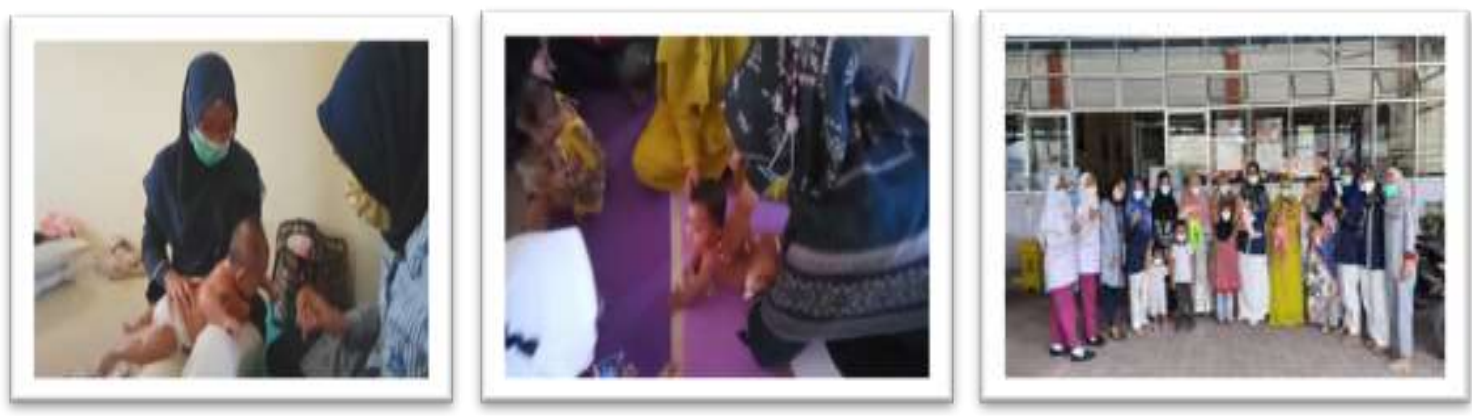

\section{Diskusi}

Pentingnya pelaksanaan kelas ibu balita ini bertujuan untuk meningkatkan kemampuan ibu memantau dan menstimulasi pertumbuhan dan perkembangan balita, Tindakan untuk mencapai tujuan ini salah satunya dengan mengajari ibu untuk melakukan pijat bayi. Stimulasi dini bayi dengan melakukan pemijatan lembut mampu mengoptimalkan pertumbuhan dan perkembangan anak. (Vicente et al., 2017).

Pengabdian masyarakat ini dihadiri oleh 5 orang ibu beserta balitanya. Berdasarkan hasil pengukuran status gizi menurut tinggi badan dan berat badan (TB/BB) didapatkan 3 orang balita memiliki status gizi normal dan 2 orang balita memiliki status gisi kurus. Pada kegiatan ini, diberikan edukasi dan mengajari teknikteknik dasar pijat bayi yang bisa dilakukan oleh ibu dirumah.

Pengetahuan pijat bayi yang diberikan meliputi tetang pengertian, manfaat, waktu pemijatan dan teknik-teknik dasar pijat bayi. Edukasi kesehatan yang diberikan kepada ibu melalui kegiatan pengabdian masyarakat ini dimaksudkan untuk mencapai tujuan dari pelaksanaan Kelas Ibu Balita. Dimana salah satu tujuan Kelas Ibu Balita adalah meningkatkan kemampuan ibu memantau pertumbuhan dan melaksanakan stimulasi perkembangan balita. Setelah diberikan edukasi tentang pijat bayi didapatkan bahwa pengetahuan ibu setelah dilakukan edukasi dinilai sangat bagus ini terlihat dari hasil koesioner yang diberikan dimana didapatkan dari 5 orang ibu 3 orang menjawab semua pertanyaan dengan benar.

Menurut Elfi dkk tahun 2018 hasil pengabdian masyarakat yang dilakukan didapatkan terjadi peningkatan pengetahuan dan kerterampilan ibu dalam pelaksanaan pijat bayi setelah diberikan pendidikan tentang pijat bayi. Banyak faktor yang mempengaruhi tingat pengetahuan dan keterampilan ibu salah satunya adalah tingkat pendidikan seseorang (Elfi et al., 2019).

Tingkat pengetahuan ibu mempengaruhi terhadap keterampilan ibu dalam melakukan pijat bayi. Bayi yang dipijat selama kurang lebih 15 menit akan merasa lebih rileks, tidur lebih lelap, perkembangan dan pertumbuhannya juga semakin baik. Saat bayi dipijat akan muncul hormone endophrin yang akan meningkatkan pertumbuhan dan perkembangan bayi, serta hormone serotinon membuat bayi lebih nyaman dan tumbuh lebih baik (Rija et al., 2020). 


\section{Kesimpulan dan Saran}

Kesimpulan dari kegiatan pengabdian masyarakat ini adalah terbentuknya kelas ibu balita di klinik MERCUBAKTIJAYA tetapi belum ada jadwal pasti kegiatan ini, pada hasil identifikasi pertumbuhan balita yang hadir adalah 2 orang balita di kategorikan kurus dan 3 orang balita dikategorikan normal dan setelah diberikan edukasi tentang pijat bayi didapatkan bahwa pengetahuan ibu meningkat setelah dilakukan edukasi. Ini terlihat dari hasil kuesioner yang diberikan dimana didapatkan dari 5 orang ibu 3 orang menjawab semua pertanyaan dengan benar.

Saran ini diberikan kepada petugas klinik MERCUBAKTIJAYA agar bisa melanjutkan kegiatan Kelas Ibu Balita yang telah dibentuk. Petugas juga harus bekerja sama dengan peserta untuk melakukan diskusi tentang nama kelas ibu balita, waktu pelaksaannya dan kegiatan-kegiatan yang dilakukan setiap bulan.

\section{Ucapan Terima Kasih}

TIM Pengabdian kepada masyarakat mengucapkan terimakasih kepada Pimpinan Klinik MERCUBAKTIJAYA yang telah memberikan izin dan kesempatan kepada TIM untuk melakukan kegiatan pengabdian kepada masyarakat di klinik. Tidak lupa TIM juga mengucapkan kepada Ketua STIKes MERCUBAKTIJAYA Padang yang telah memberikan izin dalam kegiatan ini.

\section{Daftar Referensi}

Departemen Kesehatan RI. (2011). Pedoman Pelaksanaan Kelas Ibu Balita. Jakarta: Departemen Kesehatan RI.

Dinas Kesehatan Kota Padang. (2019). Profil Kesehatan. Padang : Dinas Kesehatan Kota Padang.

Elfi, Lisnawati, \& Yuhandini, D. S. (2019). Upaya Peningkatan Keterampilan Pijat Bayi pada Kader Posyandu dan Ibu hamil Trimester III di Puskesmas Majasem Kota Cirebon Tahun 2018. EMASS : Edukasi Masyarakat Sehat Sejahtera, 1(1), 1-6.

Herliani, Y., Rohmatin, E., \& Diana, H. (2018). Pemberdayaan Ibu Balita Dalam Kegiatan Kelas Ibu Balita Untuk Meningkatkan Kemampuan Pemantauan Tumbuh Kembang Anak. Prosiding Seminar Nasional Dan Diseminasi Hasil Pengabdian Kepada Masyarakat Berbasis Riset, April, 38-41.

Pusat Badan Statistik. (2018). Profil Kesehatan Anak Indonesia Tahun 2018. In Kemnetrian Pemberdayaan Perempuan dan Perlindungan Anak.

Rija, M., Helti, \& Hasibuan, S. S. (2020). Hubungan Pengetahuan Ibu tentang Pijat Bayi dengan Kualitas Tidur Bayi Usmur 0-6 Bulan di Sekolah Emak Medan Tahun 2019. Al Ulum Seri Saintek, VIII(2), 63-69.

Vicente, S., Veríssimo, M., \& Diniz, E. (2017). Infant massage improves attitudes toward childbearing, maternal satisfaction and pleasure in parenting. Infant Behavior and Development, 49(10), 114-119. https://doi.org/10.1016/j.infbeh.2017.08.006 